\title{
Pengaruh Kinerja dan Kesehatan Keuangan Terhadap Nilai Perusahaan Pada PT. Bukit Asam, Tbk Periode 2011-2019
}

\author{
Rizky Syahrul Rahmadhan ${ }^{1}$, Aria Aji Priyanto². \\ 1) Program Studi Manajemen, Fakultas Ekonomi, Universitas Pamulang. \\ email : rizkysyahrulrahmadhan261@gmail.com \\ 2) Program Studi Manajemen, Fakultas Ekonomi, Universitas Pamulang. \\ email : dosen01048@unpam.ac.id
}

\section{ARTICLES INFORMATION}

ABSTRACT

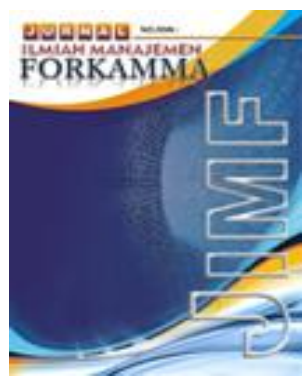

\section{JURNAL ILMIAH MANAJEMEN FORKAMMA}

\author{
Vol.4, No.2, Maret 2021 \\ Halaman : $176-191$ \\ (c) LPPM \& FORKAMMA \\ Prodi Magister Manajemen \\ UNVERSITAS PAMULANG \\ ISSN (online) : 2599-171X \\ ISSN (print) : :2598-9545
}

\section{Keyword :}

Kinerja Keuangan; Kesehatan Keuangan ; Nilai Perusahaan

JEL. classification :

O15,

Contact Author :

PRODI
MAGISTER MANAJEMEN \&
FORKAMMA UNPAM
JL.Surya Kencana No.1 Pamulang
Tangerang Selatan - Banten
Telp. (021) 7412566, Fax (021) 7412491
Email :
jurnalforkamma.unpam@gmail.com

Tujuan dari penelitian ini adalah untuk melihat price to book value yang dipengaruhi oleh return on assets dan quick ratio di industri tambang yang sudah diakui pada Bursa Efek Indonesia (BEI) yaitu PT. Bukit Asam, Tbk (PTBA) periode 2011-2019. Metode yang digunakan dalam penelitian bersifat deskriptif assosiatif dengan pendekatan kuantitatif. Populasi dalam penelitian ini menggunakan laporan keuangan perusahaan. Sampel menggunakan laporan neraca dan laporan laba-rugi PT. Bukit Asam, Tbk periode 2011-2019. Hasil penelitian yang dilakukan membuktikan variabel ROA dan QR secara simultan berpengaruh positif serta signifikan terhadap PBV. Berdasarkan hasil uji t secara parsial menunjukkan bahwa ROA berpengaruh positif dan signifikan terhadap PBV selanjutnya QR berpengaruh negatif dan signifikan terhadap PBV. ROA merupakan variabel yang berpengaruh sangat dominan terhadap PBV. Hasil dari uji koefisien determinasi menjelaskan bahwa variabel bebas berpengaruh sebesar $60,4 \%$ terhadap variabel terikat, harapannya untuk para peneliti berikutnya dapat menambah rasio yang akan digunakan dan bisa mempengaruhi PBV serta memperpanjang periode pengamatan.

The purpose of this research is to see price to book value influenced by the return on assets and quick ratio in the mining industry recognized in Indonesia Stock Exchange (IDX) that is PT. Bukit Asam, Tbk (PTBA) 2011-2019 period. The method that used to this research is associative descriptive with a quantitative approach. The population on this research is using financial statements. Sample using the balance sheet and income statement PT. Bukit Asam, Tbk for the period of 20112019. The results of this research conducted prove variable the $R O A$ and the $Q R$ simultaneously have positive and significant impact on the PBV. Based on the results of the $t$ test partially shows that ROA has a positive and significant impact on the $P B V$ next $Q R$ has a negative and significant impact on the $P B V$. $R O A$ is variable that effect very dominant on the PBV. The results of the coefficient test determination explain that the independent variable has an impact of $60,4 \%$ to the dependent variable, his hopes fot the next researcher could further the ratio of to be used and could influence on the PBV as well as extend the period of observation. 


\section{A. PENDAHULUAN}

\section{Latar Belakang Penelitian}

Saat terjadinya pandemi Covid-19 sangat berpengaruh untuk melakukan investasi dan mengakibatkan perdagangan ekspor maupun impor serta perdagangan saham menjadi terpuruk terutama pada perekonomian di Indonesia. Hal tersebut berdampak terhadap Indeks Harga Saham Gabungan (IHSG) yang menurun sangat drastis. Perusahaan industri pertambangan mengalami dampaknya dan sedikit tertekan semenjak terjadinya penyebaran Covid-19 yang tersebar ke seluruh negara, salah satunya negara Indonesia. Indikator pelemahan komoditas batu bara juga disebabkan oleh turunnya harga batu bara dunia, serta berkurangnya minat investor untuk membantu industri pertambangan. Harga batu bara yang terus merosot merupakan sebuah fenomena yang harus diperhatikan oleh negara dan menjadi tantangan tersendiri bagi perseroan. Namun fundamental pasar yang lebih kuat dibanding tahun sebelumnya membuat harganya kembali menurun.

Kondisi pasar yang langsung merespon sehingga harga saham batu bara menurun pada perdagangan saham, maka dari itu, PTBA melakukan strategi berupa pencarian potensi pasar ekspor baru supaya dapat menutupi penurunan penjualan batu bara ke negara-negara tujuan eksisting, namun penjualan batu bara ke negara-negara tujuan eksisting belum mencapai nilai yang signifikan. Hal ini dapat dimaklumi lantaran PTBA masih di tahap percobaan awal. Pada tahun 2018 PTBA mendapatkan penghargaan dari sebuah acara The Asian Export Awards 2018 dalam kategori pertambangan dan logam. Direktur Niaga PTBA yaitu bapak Adib Ubaidillah yang menerima penghargaannya di Singapore. Singapore Business Review dan Hong Kong Business yang menyelenggarakan acara terbut mempunyai tujuan yaitu untuk mengakui perusahaan ekspor produk dan jasa di wilayah Asia. Namun, jika permintaan batu bara terus meningkat, bukan tidak mungkin pangsa pasar PTBA akan bertambah dimasa mendatang agar bisa menaikkan nilai perusahaan, harga saham serta membuat para investor agar tertarik untuk menginvestasikan modal sahamnya kepada perseroan PTBA. Menurut Husnan \& Pudjiastuti (2015:84) "Price to Book Value (PBV) adalah rasio membandingkan antara harga saham per lembar dengan nilai buku ekuitas per lembar". Semakin besar nilai Price to Book Value menandakan pasar itu mempercayai progress perusahaan pertambangan dan membuktikan bahwa bisa menghasilkan nilai perusahaan yang bagus terhadap investasi dari jumlah modal yang dikeluarkan.

Pada setiap tahunnya PTBA selalu menambahkan dan mengupgarde aset yang dimilikinya agar bisa menghasilkan produk yang berkualitas sehingga jumlah laba bersih yang dihasilkan bisa maksimal. Dengan naik turunnya jumlah laba bersih serta total aset bisa mempengaruhi harga saham, jadi PTBA selalu menambahkan total aset setiap tahunnya agar bisa menghasilkan laba bersih yang maksimal. Salah satu diantara faktor keuangan adalah Rasio Profitabilitas yaitu Return On Assets (ROA) yang bisa mempengaruhi Price to Book Value (PBV). Menurut Husnan \& Pudjiastuti (2015:78) "Return On Assets (ROA) adalah rasio yang menghitung berapa banyak laba bersih setelah pajak dihasilkan oleh total aset yang dimiliki perusahaan".

Dengan menurunnya harga batu bara dan penjualan batu bara membuat PTBA kurang efektif dalam membayar kewajiban lancarnya sehingga mempengaruhi harga saham dan tingkat kepercayaan para investor terhadap PTBA. Tetapi PTBA selalu memaksimalkan aset lancarnya sehingga PTBA mampu bangkit kembali dengan produk yang baru dibuatnya yaitu batu bara kalori sedang dan rendah dirubah menjadi batu bara kalori tinggi, dengan menggunakan batu bara kalori tinggi bisa lebih efisien, karena emisinya rendah dan lebih ramah lingkungan sehingga bisa membayar kewajiban lancarnya dengan cepat. Dengan demikian faktor keuangan lain adalah Likuiditas yaitu Quick Ratio (QR) yang dapat berpengaruh terhadap naik atau turunnya Price to Book Value (PBV). Menurut Kasmir (2010:111) 
ISSN (print) : 2598-9545 \& ISSN (online) : 2599-171X

menyatakan bahwa "quick ratio atau rasio sangat lancar atau acid test ratio merupakan rasio uji cepat yang menunjukkan kemampuan perusahaan memenuhi atau membayar kewajiban atau utang lancar (utang jangka pendek) dengan aktiva lancar tanpa memperhitungkan nilai persediaan (inventory)." Dengan menggunakan rasio ini bisa mengetahui seberapa besar perusahaan PTBA mampu membayar kewajiban jangka pendeknya tanpa nilai persedian karna persediaan adalah akun yang sangat lama untuk berubah menjadi kas.

PT. Bukit Asam, Tbk menyadari untuk meningkatkan daya saing dimasa sekarang ini adalah mengoptimalisasi sumber daya yang terdapat pada aspek keuangan secara efisien dan efektif. Sebagaimana dapat ditampilkan di tabel 1:

Tabel 1. Data Laporan Keuangan PT. Bukit Asam, Tbk Periode 2011-2019

\begin{tabular}{ccccc}
\hline No & Tahun & ROA & QR & PBV \\
\hline 1 & 2011 & $26,83 \%$ & $428,23 \%$ & 0,99 \\
2 & 2012 & $22,86 \%$ & $443,48 \%$ & 0,83 \\
3 & 2013 & $15,88 \%$ & $246,70 \%$ & 0,63 \\
4 & 2014 & $12,54 \%$ & $178,26 \%$ & 0,69 \\
5 & 2015 & $12,06 \%$ & $129,30 \%$ & 0,23 \\
6 & 2016 & $10,90 \%$ & $143,72 \%$ & 0,55 \\
7 & 2017 & $20,68 \%$ & $226,58 \%$ & 2,08 \\
8 & 2018 & $21,19 \%$ & $200,08 \%$ & 3,09 \\
9 & 2019 & $15,48 \%$ & $219,49 \%$ & 1,68 \\
\hline ber : PT. Bukit Asam, Tbk, data telah diolah oleh peneliti di Microsoft Excel
\end{tabular}

Research gap dalam penelitian ini terdapat beberapa variable yang mungkin berpengaruh terhadap PBV seperti penelitiannya Amalia Nur Chasanah \& Daniel Kartika Adhi (2017) menemukan pengaruh positif signifikan dengan menggunakan variabel ROA terhadap PBV pada industri real estate yang listed di BEl serta dengan menggunakan variabel $C R$, DER dan ROA secara keseluruhan berpengaruh yang signifikan terhadap PBV. Berbeda dengan penelitiannya Bulan Oktrima (2017) tidak menemukan pengaruh ROA terhadap PBV pada PT. Mayora Indah, Tbk serta yang digunakan variabel ROA, CR dan DER secara bersama-sama berpengaruh positif terhadap PBV. Kemudian Ani Yufita \& Andayani (2019) juga tidak menemukan pengaruh dengan menggunakan variabel QR terhadap nilai perusahaan PBV pada food and beverage yang tercatat di BEI. Penelitian ini didukung oleh Elisabeth Octavia Kamal \& Indra Widjaja (2019) yang menemukan pengaruh yang signifikan terhadap PBV secara simultan dengan menggunakan variabel ROE, NPM, BOD, CR dan QR pada consumer goods yang terdaftar di BEI.

Hasil dari penjelasan penelitian terdahulu, terdapat variabel yang dapat dipergunakan untuk penelitian yang akan dilakukan, dengan menggunakan variabel Return On Assets (ROA) dan Quick Ratio (QR) terhadap Price to Book Value (PBV). Berdasarkan penjelasan yang sudah diuraikan, penulis ingin mencoba untuk meneliti mengenai PENGARUH RETURN ON ASSETS (ROA) DAN QUICK RATIO (QR) TERHADAP PRICE TO BOOK VALUE (PBV) PADA PT. BUKIT ASAM, TBK PERIODE 2011-2019.

\section{Rumusan Masalah}

Hasil dari penjabaran pada latar belakang penelitian dengan demikian dikemukakannya perumusan masalahnya yaitu:

1. Bagaimana pengaruh kinerja keuangan yang diproksikan oleh return on asset (ROA) terhadap nilai perusahaan yang diproksikan oleh price book value (PBV) pada PT. Bukit Asam, Tbk? 
2. Bagaimana pengaruh kesehatan keuangan yang diproksikan oleh quick ratio $(Q R)$ terhadap nilai perusahaan yang diproksikan oleh price book value (PBV) pada PT. Bukit Asam, Tbk?

3. Bagaimana pengaruh kinerja keuangan yang diproksikan oleh return on asset (ROA) dan kesehatan keuangan yang diproksikan oleh quick ratio $(\mathrm{QR})$ terhadap nilai perusahaan yang diproksikan oleh price book value (PBV) pada PT. Bukit Asam, Tbk?

\section{Tujuan Penelitian}

Supaya penelitian yang dilakukan ini setujuan dengan rumusan masalahnya maka ditetapkan tujuan penelitiannya yaitu:

1. Untuk mengetahui pengaruh kinerja keuangan yang diproksikan oleh return on asset (ROA) terhadap nilai perusahaan yang diproksikan oleh price book value (PBV) pada PT. Bukit Asam, Tbk

2. Untuk mengetahui pengaruh kesehatan keuangan yang diproksikan oleh quick ratio (QR) terhadap nilai perusahaan yang diproksikan oleh price book value (PBV) pada PT. Bukit Asam, Tbk

3. Untuk mengetahui pengaruh kinerja keuangan yang diproksikan oleh return on asset (ROA) dan kesehatan keuangan yang diproksikan oleh quick ratio (QR) ) terhadap nilai perusahaan yang diproksikan oleh price book value (PBV) pada PT. Bukit Asam, Tbk

\section{B. KAJIAN LITERATUR}

\section{Definisi Laporan Keuangan}

Laporan keuangan menunjukkan keadaan keuangan serta usaha yang dihasilkan pada sebuah perusahaan disaat kondisi dan waktu yang ditentukan. Biasanya seseorang melakukan analisis dengan menggunakan laporan keuangan karna sangat penting untuk melihat kinerja perusahaan serta kondisi keuangannya. Menurut Husnan \& Pudjiastuti (2015:63) "Iaporan keuangan adalah laporan yang disusun menurut prinsip-prinsip akuntansi dengan menyajikan informasi keuangan yang dijadikan sebagai neraca dan laporan laba rugi". Menurut Munawir (2007:5) "pada umumnya laporan keuangan itu terdiri dari neraca dan perhitungan laba-rugi serta laporan perubahan ekuitas. Neraca menunjukkan atau menggambarkan jumlah aset, kewajiban dan ekuitas dari suatu perusahaan pada tanggal tertentu. Sedangkan perhitungan laporan laba-rugi memperlihatkan hasil-hasil yang telah dicapai oleh perusahaan serta biaya yang terjadi selama periode tertentu, dan laporan perubahan ekuitas menunjukkan sumber dan penggunaan atau alasan-alasan yang menyebabkan perubahan ekuitas perusahaan".

\section{Analisis Rasio Keuangan}

Menurut Kasmir (2010:93) "rasio keuangan merupakan kegiatan membandingkan angkaangka yang ada dalam laporan keuangan dengan cara membagi satu angka dengan angka lainnya". Sedangkan menurut Husnan \& Pudjiastuti (2015:75) "analisis rasio keuangan dilakukan untuk mempermudah penganalisa (analisis) memahami kondisi keuangan perusahaan. Dengan melihat angka-angka apa adanya yang tercantum pada neraca dan laba rugi, sering sulit untuk memperoleh gambaran yang jelas tentang kondisi perusahaan. Untuk melakukan analisis rasio keuangan diperlukan perhitungan rasio-rasio keuangan yang mengukur aspek-aspek tertentu".

Selanjutnya menurut Munawir (2007:106) "analisa rasio keuangan adalah future oriented atau berorientasi dengan masa depan, artinya bahwa dengan analisa rasio keuangan dapat digunakan sebagai alat untuk meramalkan keadaan keuangan serta hasil usaha di masa yang akan datang".

\section{Nilai Perusahaan (Price to Book Value / PBV)}

Menurut Fahmi (2014:82) "nilai perusahaan adalah rasio nilai pasar yaitu rasio yang menggambarkan kondisi yang terjadi di pasar. Rasio ini mampu memberikan pemahaman bagi pihak manajemen perusahaan terhadap kondisi penerapan yang akan dilaksanakan dan 
dampaknya pada masa yang akan datang". Menurut Fahmi (2014:139) "Price to Book Value (PBV) adalah rasio ini menggambarkan seberapa besar pasar menghargai nilai buku saham perusahaan". Menurut Weston \& Copeland (2010:245) "Price to Book Value (PBV) menggambarkan seberapa besar pasar menghargai nilai buku saham suatu perusahaan. Semakin tinggi Price to Book Value, berarti pasar percaya akan prospek perusahaan tersebut. Price to Book Value juga menunjukkan seberapa jauh suatu perusahaan mampu menciptakan nilai perusahaan yang relatif terhadap jumlah modal yang diinvestasikan." Sedangkan menurut Husnan \& Pudjiastuti (2015:84) "Price to Book Value (PBV) adalah rasio membandingkan antara harga saham per lembar dengan nilai buku ekuitas per lembar".

\section{Kinerja Keuangan (Return On Assets / ROA)}

Menurut Priyanto (2019:66) "ROA adalah salah satu bentuk rasio profitabilitas / kinerja keuangan yang cukup terkenal untuk menggambarkan daya tarik bisnis perusahaan". Menurut Rudianto (dalam jurnal Priyanto, 2021:192) "semakin tinggi nilai ROA maka akan menunjukkan perusahaan memiliki kinerja yang semakin baik. Investor akan menaruh kepercayaan kepada pihak manajemen bahwa manajemen akan mengelola aset secara efektif untuk mencapai laba yang optimal bagi shareholders". Menurut Kasmir (2010:115) "Return On Assets (ROA) merupakan rasio yang menunjukkan hasil (return) untuk mengukur laba bersih sesudah pajak atas jumlah aktiva yang digunakan dalam perusahaan".

Menurut Munawir (2007:88) "Return On Assets (ROA) merupakan rasio antara jumlah aktiva yang digunakan dalam operasi (operating assets) terhadap jumlah penjualan yang diperoleh selama periode tersebut". Menurut Priyanto (2019:65) "Return On Asset (ROA) atau disebut juga rasio yang menunjukan persentase keuntungan (laba bersih) yang diperoleh perusahaan sehubungan dengan keseluruhan sumber daya atau rata-rata jumlah aset". Menurut Husnan \& Pudjiastuti (2015:78) "Return On Assets (ROA) adalah rasio yang menghitung berapa banyak laba bersih setelah pajak dihasilkan oleh total aset yang dimiliki perusahaan. Rasio ini banyak yang menghitung meskipun ada ketidak tepatan ketika kita membandingkan antara laba bersih setelah pajak (berarti laba operasi sudah dikurangi biaya bunga dan pajak penghasilan) - yang sebenarnya merupakan hak pemilik ekuitas - dengan total aset (yang sebagian diantanya mungkin dibiayai dengan hutang)".

\section{Kesehatan Keuangan (Quick Ratio / QR)}

Menurut Kasmir (2010:111) menyatakan bahwa "Quick Ratio (QR) atau rasio sangat lancar atau acid test ratio merupakan rasio uji cepat yang menunjukkan kemampuan perusahaan memenuhi atau membayar kewajiban atau utang lancar (utang jangka pendek) dengan aktiva lancar tanpa memperhitungkan nilai persediaan (inventory)." Nilai persediaan tidak dimasukkan karena dibutuhkan waktu yang sangat lama untuk dicairkan dalam bentuk uang, ketika perusahaan tersebut perlu dana yang lancar untuk melunasi kewajibannya. Menurut Munawir (2007:74) "Quick Ratio (QR) yaitu perbandingan antara (aktiva lancar-persediaan) dengan hutang lancar. Ratio ini merupakan ukuran kemampuan perusahaan dalam memenuhi kewajiban-kewajibannya dengan tidak memperhitungkan persediaan, karena persediaan memerlukan waktu yang relatif lama untuk direalisir menjadi uang kas dan menganggap bahwa piutang segera dapat direalisir sebagai uang kas, walaupun kenyataannya mungkin persediaan lebih likuid dari pada piutang". Menurut Husnan \& Pudjiastuti (2015:83) "Quick Ratio (QR) adalah rasio cepat, suatu persediaan merupakan akun yang paling lama untuk berubah menjadi kas (yaitu harus berubah dulu menjadi piutang), dan tingkat kepastian nilainya rendah (nilai persediaan mungkin tidak seperti yang tercantum pada neraca seandainya dijual, terutama barang dalam proses), maka akun persediaan dikeluarkan dari perhitungan".

\section{Hasil Penelitan Terdahulu}

Berdasarkan penelitian terdahulu yang dilakukan oleh (Chasanah \& Adhi, 2017) dengan judul profitabilitas, struktur modal dan likuiditas pengaruhnya terhadap nilai perusahaan pada perusahaan real estate yang listed di BEI Tahun 2012-2015 temuan penelitian tersebut 

Selain itu ada variabel CR yang tidak berpengaruh terhadap PBV. Variabel ROA, CR dan DER mempunyai nilai adjusted $\mathrm{R}$ square sebesar 0,206 yang membuktikan hanya punya pengaruh sebanyak 20,6\% terhadap PBV. Penelitian yang dilakukan oleh (Kamal \& Widjaja, 2019) dengan judul pengaruh profitabilitas, board gender, dan likuiditas terhadap nilai perusahaan dengan kebijakan dividen sebagai variabel moderasi (studi empiris pada perusahaan manufaktur yang bergerak dibidang consumer goods yang terdaftar di BEI periode 2011-2016) temuan penelitian menyatakan variabel BOD, CR, ROE, NPM dan QR secara kesuluruhan berpengaruh positif serta signifikan terhadap PBV. Variabel ROE, NPM, BOD, CR, dan QR dengan DPR sebagai variabel moderasi berpengaruh positif signifikan terhadap PBV. Secara masing-masing variabel $\mathrm{CR}$ berpengaruh positif tidak signifikan terhadap PBV dan QR berpengaruh negatif tidak signifikan terhadap PBV. ROE dan BOD berpengaruh positif signifikan terhadap PBV, sedangkan NPM berpengaruh negatif signifikan terhadap PBV. Variabel independen menjelaskan variasi variabel dependen sebesar 94,3\% sedangkan sisanya $5,7 \%$ dipengaruhi oleh faktor lain yang tidak dimasukkan dalam model regresi ini. Interaksi variabel independen dengan variabel moderasi dapat menjelaskan variasi variabel dependen sebesar $95,0 \%$ sedangkan residunya $5 \%$ berpengaruh bukan dengan faktor ini.

\section{Kerangka Berfikir}

Kerangka berpikir akan bagus jika menerangkan hubungan antara variabel yang akan ditelitinya. Menurut Uma Sekaran (dalam Sugiyono, 2017:60) "kerangka berfikir merupakan model konseptual tentang bagaimana teori berhubungan dengan berbagai faktor yang telah di identifikasi sebagai masalah yang penting". Ada juga model kerangka berfikir yang dikembangkan berdasarkan hasil dari pengkajian pustaka dan penelitian terdahulu, dapat diilustrasikan pada Gambar 1. berikut:

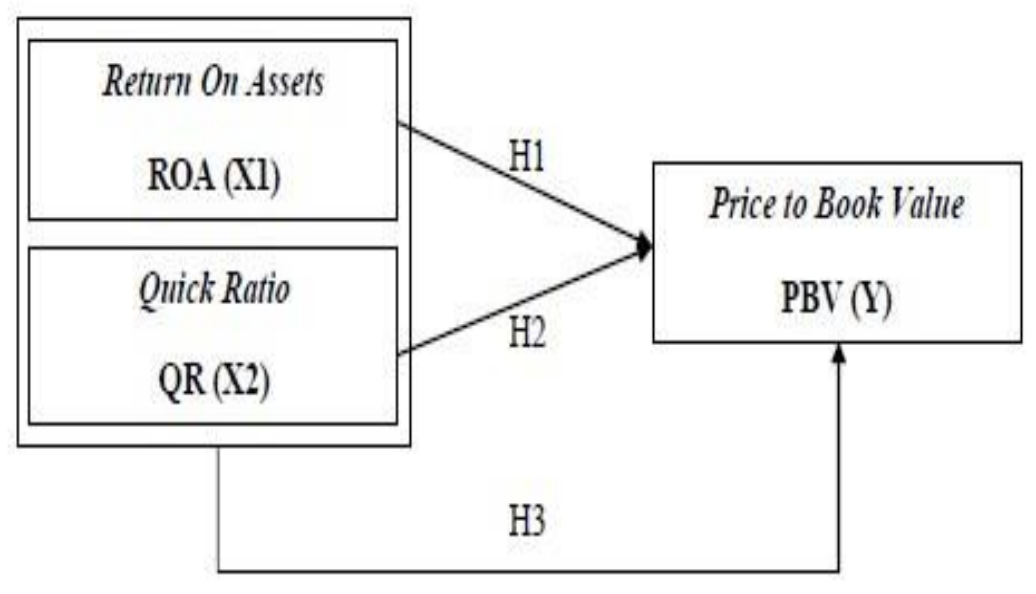

\section{Gambar 1. Model Kerangka Berfikir}

Kerangka berfikir diturunkan ke dalam perumusan hipotesis berikut ini:

$\mathrm{H} 1$ \# 0 : Terdapat pengaruh signifikan antara kinerja keuangan yang diproksikan oleh return on asset (ROA) terhadap nilai perusahaan yang diproksikan oleh price book value (PBV) pada PT. Bukit Asam, Tbk

$\mathrm{H} 2$ \# $0 \quad$ : $\quad$ Terdapat pengaruh signifikan antara kesehatan keuangan yang diproksikan oleh quick ratio $(\mathrm{QR})$ terhadap nilai perusahaan yang diproksikan oleh price book value (PBV) pada PT. Bukit Asam, Tbk

H3 \# 0 : Terdapat kinerja keuangan yang diproksikan oleh return on asset (ROA) dan kesehatan keuangan yang diproksikan oleh quick ratio (QR) ) terhadap nilai perusahaan yang diproksikan oleh price book value (PBV) pada PT. Bukit Asam, Tbk 


\section{METODOLOGI PENELITIAN}

\section{Jenis Data}

Dalam pembuatan skripsi ini dengan jenis penelitian kuantitatif yang akan dipergunakan. Menurut Sugiyono (2017:8) menyatakan "metode penelitian kuantitatif dapat diartikan sebagai metode penelitian yang berlandaskan pada filsafat positivisme, digunakan untuk meneliti pada populasi atau sampel tertentu, pengumpulan data menggunakan instrumen penelitian, analisis data bersifat kuantitatif/statistik, dengan tujuan untuk menguji hipotesis yang telah ditetapkan". Dimana penelitian ini mengumpulkan, menganalisis, menghitung jumlah dari data laporan keuangan pada perusahaan PT. Bukit Asam, Tbk Periode 2011-2019.

Dalam menyusun skripsi ini bersifat deskriptif assosiatif. Menurut Sugiyono (2017:35) mengemukakan bahwa "deskriptif adalah suatu rumusan masalah yang berkenaan dengan pernyataan terhadap keberadaan variabel mandiri, baik hanya pada satu variabel atau lebih (variabel yang berdiri sendiri)". Selanjutnya menurut Sugiyono (2017:37) "assosiatif adalah suatu rumusan masalah penelitian yang bersifat menanyakan hubungan antara dua variabel atau lebih. Terdapat tiga bentuk hubungan yaitu: hubungan simetris adalah suatu hubungan antara dua variabel atau lebih yang kebetulan munculnya bersama, hubungan kausal adalah hubungan yang bersifat sebab akibat, dan interaktif/resiprokal/timbal balik adalah hubungan yang saling mempengaruhi".

\section{Sumber Data}

Menurut Sugiyono (2017:80) menyatakan bahwa "populasi adalah wilayah generalisasi yang terdiri atas: obyek/subyek yang mempunyai kualitas dan karakteristik tertentu yang ditetapkan oleh peneliti untuk dipelajari dan kemudian ditarik kesimpulannya". Secara umum populasi merupakan suatu objek yang akan diteliti serta proses dalam pengumpulan datanya mempunyai karakteristik yang sama. Dalam penelitian ini populasinya mengggunakan laporan keuangan perusahaan PT. Bukit Asam, Tbk. Sampel ialah bagian dari populasi yang akan diteliti oleh peneliti. Menurut Sugiyono (2017:81) "sampel adalah bagian dari jumlah dan karakteristik yang dimiliki oleh populasi tersebut." Sampel ditentukan tekniknya berdasarkan kriteria atau pertimbangan tertentu antara lain: sampel yang digunakan adalah laporan laba-rugi serta laporan neraca PT. Bukit Asam, Tbk periode 2011-2019.

\section{Teknik Pengumpulan Data}

Menurut Sugiyono (2017:224) "teknik pengumpulan data merupakan langkah yang paling strategis dalam penelitian, karena tujuan utama dari penelitian adalah mendapatkan data. Tanpa mengetahui teknik pengumpulan data, maka peneliti tidak akan mendapatkan data yang memenuhi standar data yang ditetapkan". Data dikumpulkan dengan cara studi pustaka untuk memahami literatur lalu dibuat materi yang bersangkutan dengan penelitian serta memahami laporan keuangan dan mencari data yang diperlukan kemudian melakukan perhitungan dan pencatatan hasilnya. Maka penelitian ini menggunakan data sekunder dan teknik dokumentasi berdasarkan laporan keuangan $\quad$ PT. Bukit Asam, Tbk periode 2011-2019.

\section{Operasional Variabel}

Menurut Sugiyono (2017:39) "variabel penelitian adalah suatu atribut atau sifat atau nilai dari orang, obyek atau kegiatan yang mempunyai variasi tertentu yang ditetapkan oleh peneliti untuk dipelajari dan kemudian ditarik kesimpulannya". Menurut Sugiyono (2017:39) "variabel independen sering disebut sebagai variabel stimulus, predictor, antecedent. Dalam bahasa Indonesia sering disebut sebagai variabel bebas. Variabel bebas merupakan variabel yang mempengaruhi atau yang menjadi sebab perubahannya atau timbulnya variabel dependen 
(terikat)“. Variabel independen pertama dalam penelitian ini adalah Return On Assets (ROA) sebagai variabel $\mathrm{X} 1$.

R0A $=\frac{\text { Laba Setelah Pajak }}{\text { Total Aset }} \times 100 \%$ Husnan \& Pudjiastuti (2015:78)

Variabel independen kedua dalam penelitian ini adalah Quick Ratio (QR) sebagai variabel X2.

$$
\mathrm{QR}=\frac{\text { Aset Lancar }- \text { Persedian }}{\text { Kewajiban Lancar }} x 100 \% \quad \text { Husnan \& Pudjiastuti }(2015: 83)
$$

Menurut Sugiyono (2017:39) "variabel dependen sering disebut sebagai variabel output, kriteria, konsekuen. Dalam bahasa Indonesia sering disebut sebagai variabel terikat. Variabel terikat merupakan variabel yang dipengaruhi atau yang menjadi akibat, karena adanya variabel bebas" Variabel dependen dalam penelitian ini adalah Price to Book Value (PBV) sebagai variabel $(Y)$.

$$
\mathrm{PBV}=\frac{\text { Harga Saham per Lembar }}{\text { Nilaĩ Buku Ekuitas per Lembar Saham }} \quad \text { Husnan \& Pudjiastuti (2015:84) }
$$

\section{Teknik Analisis Data}

Menurut Sugiyono (2017:243) "dalam penelitian kuantitatif, teknik analisis data yang digunakan sudah jelas, yaitu diarahkan untuk menjawab rumusan masalah atau menguji hipotesis yang telah dirumuskan dalam proposal. Karena datanya kuantitatif, maka teknik analisis data menggunakan metode statistik yang sudah tersedia“. Dalam penelitian ini menggunakan teknik analisis data dengan metode analisa data kuantitatif yang terdiri dari analisis statisktik deskriptif, analisis statistik melalui tahapan perhitungan menggunakan SPSS versi 20 didalamnya ada uji normalitas, uji multikolinearitas, uji heteroskedastisitas, uji autokolerasi, analisis regresi liniear sederhana, analisis regresi liniear berganda, uji koefisien determinasi, uji parsial t, uji simultan F.

\section{HASIL DAN PEMBAHASAN}

\section{Analisis Statistik Deskriptif}

Digunakan sebagai uji yang memberikan suatu gambaran data pada variabel yang akan dipakai. Dalam analisis statistik deskriptif pada penelitian ini yang data digunakan adalah nilai maksimum, minimum, standar deviasi dan rata-rata (mean). Dapat ditampilkan hasilnya pada Tabel 2.:

Tabel 2. Analisis Statistik Deskriptif Descriptive Statistics

\begin{tabular}{lrrrrr}
\hline & \multicolumn{1}{c}{ N Minimum Maximum } & Mean & $\begin{array}{c}\text { Std. } \\
\text { Deviation }\end{array}$ \\
\hline Return On Assets & 9 & 10,90 & 26,83 & 17,6022 & 5,52124 \\
Quick Ratio & 9 & 129,30 & 443,48 & 246,2064 & 114,05240 \\
Price to Book & 9 &, 23 & 3,09 & 1,1967 &, 91557 \\
Value & & & & &
\end{tabular}


Berdasarkan Tabel 2 dapat disimpulkan bahwa:

1. Variabel Kinerja keuangan yang diproksikan oleh Return On Assets (ROA) nilai minimumnya adalah 10,90 , nilai maksimumnya adalah 26,83 , standar deviasinya sebesar 5,52124 dan nilai rata-ratanya sebesar 17,6022 , dapat diketahui bahwa perusahaan bisa menghasilkan laba sebesar $17,60 \%$ dari setiap total aset yang dimilikinya.

2. Variabel Kesehatan Keuangan yang diproksikan oleh Quick Ratio (QR) nilai minimumnya adalah 129,30, nilai maksimumnya adalah 443,48, standar deviasi sebesar 114,05240 dan nilai rata-ratanya sebesar 246,2064, dapat dikatakan bahwa perusahaan mampu mengembangkan usahanya dengan aset lancar yang dimiliki sebesar $246,21 \%$ dari setiap pembayaran kewajiban lancarnya.

3. Variabel Nilai Perusahaan yang diproksikan oleh Price to Book Value (PBV) nilai minimumnya adalah 0,23, nilai maksimumnya adalah 3,09, standar deviasi sebesar 0,91557 dan nilai rata-ratanya sebesar 1,1967, dapat dijelaskan bahwa rata-rata perusahaan mampu menaikan harga saham per lembarnya sebesar 1,20\% atas nilai buku ekuitas per lembar saham.

\section{Uji Normalitas}

Pengujian yang paling pertama dalam uji asumsi klasik, biasanya buat menguji data penelitian dari variabel dependen atau variabel independen apakah ke 2nya punya distribusi normal/tidak dalam sebuah model regresi ini. Model regresi akan bagus jika mempunyai distribusi data yang normal. Berikut hasil ujinya, dapat ditampilkan hasilnya pada Tabel 3.:

Tabel 3. Hasil Uji Normalitas K-S One-Sample Kolmogorov-Smirnov Test

\begin{tabular}{llr}
\hline & & \multicolumn{2}{c}{$\begin{array}{c}\text { Unstandardized } \\
\text { Residual }\end{array}$} \\
\hline $\mathrm{N}$ & Mean & 9 \\
\multirow{2}{*}{ Normal Parameters } & (b)b &, 000000 \\
& Std. &, 49902850 \\
Most Extreme & Deviation &, 181 \\
Differences & Absolute &, 126 \\
Kolmogorov-Smirnov Z & Positive &,- 181 \\
Asymp. Sig. (2-tailed) & Negative &, 544 \\
\hline
\end{tabular}

a. Test distribution is Normal.

b. Calculated from data.

Sumber : Output SPSS Versi 20, Januari 2021

Dengan menggunakan One-Sample Kolomogorov-Smirnov hasilnya menunjukkan nilai signifikansinya sebesar $0,929>0,05$ dapat dikatakan data dalam penelitian ini mempunyai distribusi yang normal.

\section{Uji Multikolinearitas}

Dipakai buat membuktikan pada model regresi apakah ditemukan kolerasi disetiap variabel independen, terjadinya multikolinearitas dikarnakan adanya korelasi. Hasil yang bagus dari 
model regresi itu tidak ditemukan kolerasi diantara variabel independen. Hasil dari uji multikolinearitas ditampilkan pada Tabel 4. seperti berikut ini:

\begin{tabular}{|c|c|c|}
\hline \multirow[t]{2}{*}{ Model } & \multicolumn{2}{|c|}{$\begin{array}{c}\text { Collinearity } \\
\text { Statistics }\end{array}$} \\
\hline & Tolerance & VIF \\
\hline (Constant) & & \\
\hline $\begin{array}{l}\text { Return On } \\
\text { Assets }\end{array}$ & 296 & 3,374 \\
\hline Quick Ratio & ,296 & 3,374 \\
\hline
\end{tabular}

a. Dependent Variable: Price to Book

Value

Sumber : Output SPSS Versi 20, Januari 2021

Pada hasil tersebut menunjukkan bahwa ROA dan QR memiliki Tolerance sebesar 0,296 dan VIF sebesar 3,374. Dari hasil datanya menyatakan bahwa nilai Tolerance 0,296 $\geq 0,10$ dan VIF 3,374 $\leq 10$. Dapat diambil kesimpulannya bahwa tidak terjadi multikolinearitas dari kedua variabel independen yang diuji.

\section{Uji Heteroskedastisitas}

Pada model regresi dalam uji ini dengan mempergunakan grafik scatterplot, jika pola titiknya menyebar secara random, tidak tertumpuk pada satu wilayah serta polanya tidak membentuk dalam model tertentu, dengan demikian bisa dikatakan tidak terjadinya heteroskedastisitas. Hasilnya dapat ditampilkan pada Gambar 2. seperti berikut ini:

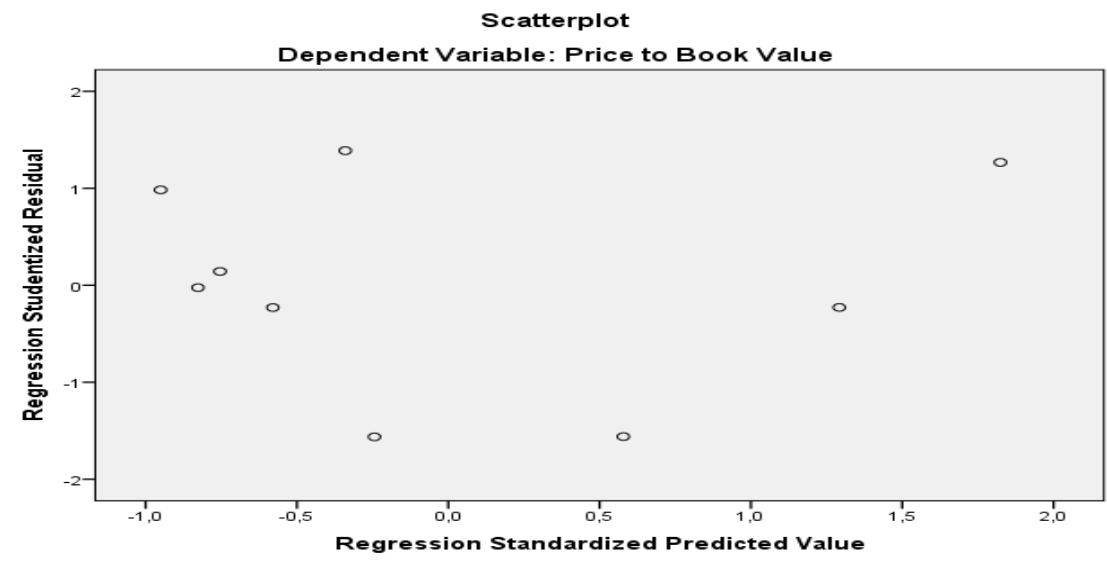

Sumber : Output SPSS Versi 20, Januari 2021

\section{Gambar 2. Hasil Uji Heteroskedastisitas Grafik Scatterplot}

Dapat diketahui dari Gambar 2. titiknya menyebar luas secara random serta polanya tidak jelas, jadi bisa diambil kesimpulannya penelitian yang dilakukan tidak terjadi heteroskedastitas.

\section{Uji Autokolerasi}

Digunakan untuk membuktikan dalam suatu bentuk regresi linear apakah ditemukannya korelasi terhadap penyimpangan peganggu diperiode saat ini dengan periode sebelumnya. Biasanya untuk menguji antar residual apakah adanya kolerasi yang tinggi maka digunakannya uji run test. Jika disetiap residual tidak ada hubungan kolerasi artinya residual tersebut random. Hasil dari uji run test bisa ditampilkan pada Tabel 5. berikut ini: 
Tabel 5. Hasil Uji Autokolerasi Run Test

Runs Test

\begin{tabular}{lr}
\hline & $\begin{array}{c}\text { Unstandardized } \\
\text { Residual }\end{array}$ \\
\hline Test Value &,- 01187 \\
Cases < Test & 4 \\
Value & \\
Cases $>=$ Test & 5 \\
Value & 9 \\
Total Cases & 8 \\
Number of Runs & 1,486 \\
$Z$ &, 137 \\
Asymp. Sig. (2- & \\
tailed) & \\
\hline a. Median & \\
Sumber : Output SPSS Versi 20, Januari 2021
\end{tabular}

Berdasarkan Tabel 5. nilai signifikannya $0,137>0,05$, bisa dikatakan tidak terjadi gejala autokolerasi. Dari hasil uji asumsi klasik yang sudah dilakukan menyatakan bahwa memiliki distribusi data yang normal, sehingga penelitian dapat dilanjutkan.

\section{Analisis Regresi Linier Sederhana}

Dalam analisis buat membuktikan ada atau tidaknya pengaruh antara satu variabel bebas terhadap variabel terikat yang mana didalam penelitian ini memiliki tiga buah variabel yaitu 2 variabel independen (X1 dan $\mathrm{X} 2$ ) dan 1 variabel dependen $(Y)$. Kemudian uji satu persatu dari setiap variabel antara $\mathrm{X} 1$ terhadap $\mathrm{Y}$ dan juga $\mathrm{X} 2$ terhadap $\mathrm{Y}$. Berikut adalah hasil data pengaruh ROA terhadap PBV:

Tabel 6. Hasil Uji Linier Sederhana (ROA Terhadap PBV) Coefficients $^{a}$

\begin{tabular}{|c|c|c|c|c|c|}
\hline \multirow[t]{2}{*}{ Model } & \multicolumn{2}{|c|}{ Unstandardized Coefficients } & \multirow{2}{*}{$\begin{array}{c}\text { Standardized Coefficients } \\
\text { Beta }\end{array}$} & \multirow[t]{2}{*}{$\mathrm{t}$} & \multirow[t]{2}{*}{ Sig. } \\
\hline & $B$ & Std. Error & & & \\
\hline${ }_{1}$ (Con &,- 094 & 1,032 & &,- 091 & 930 \\
\hline Return On Assets & ,073 & ,056 & 442 & 1,304 & 233 \\
\hline
\end{tabular}

a. Dependent Variable: Price to Book Value

Sumber : Output SPSS Versi 20, Januari 2021

Pada Tabel 6. dapat diketahui nilai konstanta sebesar -0,094. Dan koefisien regresi ROA adalah 0,073 artinya bahwa setiap kenaikan $1 \%$ tingkat ROA maka PBV juga naik sebanyak 0,073 . Sebab nilainya positif jadi dapat dikatakan ROA berpengaruh positif terhadap PBV. Berikut adalah hasil data pengaruh QR terhadap PBV:

Tabel 7. Hasil Uji Linier Sederhana (QR Terhadap PBV) Coefficients $^{a}$

\begin{tabular}{|c|c|c|c|c|c|}
\hline Model & Unstandardizec & Coefficients & Standardized Coefficients & $t$ & Sig. \\
\hline & $\mathrm{B}$ & Std. Error & Beta & & \\
\hline $1(\mathrm{Col}$ & 1,230 & ,815 & & 1,509 & 175 \\
\hline Quick Ratio & $-0,000136$ & ,003 &,- 017 &,- 045 & ,966 \\
\hline
\end{tabular}

a. Dependent Variable: Price to Book Value

Sumber : Output SPSS Versi 20, Januari 2021 
Pada Tabel 7. dapat diketahui nilai konstanta sebesar 1,230. Dan koefisien regresi $Q R$ adalah $-0,000136$ artinya bahwa setiap kenaikan $1 \%$ tingkat QR maka PBV juga naik sebanyak $-0,000136$. Sebab nilainya negatif jadi dapat dikatakan QR berpengaruh negatif terhadap PBV.

\section{Analisis Regresi Linier Berganda}

Dipakai buat membuktikan berapa besarnya pengaruh variabel $\mathrm{X}$ terhadap $\mathrm{Y}$, yaitu pengaruh ROA dan QR terhadap PBV. Hasilnya bisa ditampilkan pada Tabel 8.:

Tabel 8. Hasil Uji Regresi Linier Berganda Coefficients $^{\mathrm{a}}$

\begin{tabular}{|c|c|c|c|c|c|}
\hline Model & Unstandard & d Coefficients & Standardized Coefficients & $t$ & Sig. \\
\hline & $B$ & Std. Error & Beta & & \\
\hline (Constant) &,- 712 & ,704 & & $-1,010$ & ,351 \\
\hline 1 Return On Assets & ,255 & 068 & 1,540 & 3,767 & ,009 \\
\hline Quick Ratio &,- 011 &, 003 & $-1,308$ & $-3,201$ &, 019 \\
\hline
\end{tabular}

a. Dependent Variable: Price to Book Value

Sumber : Output SPSS Versi 20, Januari 2021

Pada hasil perhitungan Tabel 8. coefficients diatas diperoleh persamaan regresi sebagai berikut:

$$
\mathrm{Y}=\mathrm{a}+\mathrm{b} 1 . \mathrm{X} 1+\mathrm{b} 2 . \mathrm{X2}
$$

PBV $=-0,712+0,255+-0,011$

Persamaan regresi linear berganda memiliki interprestasi seperti ini:

1. Konstanta (a) sebesar $-0,712$ artinya apabila perubahan variabel Return On Assets (ROA) dan Quick Ratio $(\mathrm{QR})$ konstantanya bernilai nol $(\mathrm{ROA}$ dan $\mathrm{QR}=0)$, jadi nilai PBV adalah 0,712 .

2. Variabel ROA sebesar 0,255 jadi apabila variabel independen lain nilainya sama dan ROA mengalami kenaikan 1 kali maka PBV (Y) akan mengalami kenaikan sebesar 0,255. Karena koefisien nilainya positif artinya terjadi hubungan yang positif antara ROA dengan PBV, semakin naik nilai ROA maka semakin naik juga nilai PBV.

3. Variabel $Q R$ sebesar $-0,011$ jadi apabila variabel independen lain nilainya sama dan $Q R$ mengalami perubahan 1 kali, maka PBV (Y) akan mengalami penurunan sebesar -0,011. Karena koefisien nilainya negatif artinya terjadi hubungan yang negatif antara QR dengan PBV, semakin naik nilai QR maka PBV semakin turun.

\section{Uji Koefisien Determinasi}

Dipakai buat membuktikan besarnya persentasi yang disumbangkan dari semua variabel independen kepada variabel selanjutnya. Hasilnya bisa ditampilkan pada Tabel 9. seperti berikut ini:

Tabel 9. Hasil Uji Koefisien Determinasi Model Summary ${ }^{b}$

\begin{tabular}{|c|c|c|c|c|}
\hline Model & $\mathrm{R}$ & $\begin{array}{c}\mathrm{R} \\
\text { Square }\end{array}$ & $\begin{array}{l}\text { Adjusted R } \\
\text { Square }\end{array}$ & $\begin{array}{l}\text { Std. Error of the } \\
\text { Estimate }\end{array}$ \\
\hline 1 &, $838^{a}$ & ,703 & 604 &, 57623 \\
\hline
\end{tabular}


Pada Tabel 9. menyatakan bahwa besarnya persentasi variabel yang berpengaruh dapat dilihat pada Adjusted $\mathrm{R}^{2}=0,604$ atau $60,4 \%$, maka bisa diambil kesimpulannya ROA dan QR berpengaruh sebesar $60,4 \%$ terhadap PBV, sehingga residunya adalah $39,6 \%$ variabel lain yang akan mempengaruhinya.

\section{Uji Parsial (Uji t)}

Dipakai buat membuktikan pada setiap variabel bebas apakah punya pengaruh yang signifikan kepada variabel terikat. Data tersebut harus diuji untuk mencari tau hubungan keduanya. Hasil dari uji parsial bisa ditampilkan pada Tabel 10.:

\section{Tabel 10. Hasil Uji Parsial (Uji t)} Coefficients $^{\mathrm{a}}$

\begin{tabular}{|c|c|c|c|c|c|}
\hline \multirow[t]{2}{*}{ Model } & \multicolumn{2}{|c|}{$\begin{array}{l}\text { Unstandardize } \\
\text { d Coefficients }\end{array}$} & \multirow{2}{*}{$\begin{array}{c}\text { Standardize } \\
d \\
\text { Coefficients } \\
\text { Beta }\end{array}$} & \multirow[t]{2}{*}{$t$} & \multirow[t]{2}{*}{ Sig. } \\
\hline & B & $\begin{array}{l}\text { Std. } \\
\text { Error }\end{array}$ & & & \\
\hline (Constant) & ,712 & ,704 & & 1,010 & ,351 \\
\hline $1 \begin{array}{l}\text { Return On } \\
\text { Assets }\end{array}$ & ,255 & ,068 & 1,540 & 3,767 & ,009 \\
\hline Quick Ratio & , 011 & ,003 & $-1,308$ & $3,201^{-}$ & ,019 \\
\hline
\end{tabular}

a. Dependent Variable: Price to Book Value

Sumber : Output SPSS Versi 20, Januari 2021

Titik Persentase Distribusi t $(\mathrm{df}=1-40)$

\begin{tabular}{|c|c|c|c|c|c|c|c|}
\hline $\mathrm{Pr}$ & $\begin{array}{l}0.25 \\
0.50 \\
\end{array}$ & $\begin{array}{l}0.10 \\
0.20 \\
\end{array}$ & $\begin{array}{l}0.05 \\
0.10 \\
\end{array}$ & $\begin{array}{l}0.025 \\
0.050 \\
\end{array}$ & $\begin{array}{l}0.01 \\
0.02 \\
\end{array}$ & $\begin{array}{l}0.005 \\
0.010 \\
\end{array}$ & $\begin{array}{l}0.001 \\
0.002\end{array}$ \\
\hline 1 & 1.00000 & 3.07768 & 6.31375 & 12.70620 & 31.82052 & 63.65674 & 318.30884 \\
\hline 2 & 0.81650 & 1.88562 & 2.91999 & 4.30265 & 6.96456 & 9.92484 & 22.32712 \\
\hline 3 & 0.76489 & 1.63774 & 2.35336 & 3.18245 & 4.54070 & 5.84091 & 10.21453 \\
\hline 4 & 0.74070 & 1.53321 & 2.13185 & 2.77645 & 3.74695 & 4.60409 & 7.17318 \\
\hline 5 & 0.72669 & 1.47588 & 2.01505 & 2.57058 & 3.36493 & 4.03214 & 5.89343 \\
\hline 6 & 0.71756 & 1.43976 & 1.94318 & 2.44691 & 3.14267 & 3.70743 & 5.20763 \\
\hline 7 & 0.71114 & 1.41492 & 1.89458 & 2.36462 & 2.99795 & 3.49948 & 4.78529 \\
\hline
\end{tabular}

Sumber : Distribusi tabel

1. Variabel $R O A$ memperoleh nilai $t_{\text {hitung }}$ sebesar 3,767 , sedangkan $t_{\text {tabel }}$ adalah 2,447 . Lalu dibuatnya untuk memperbandingkan yakni thitung 3,767 $>t_{\text {tabel }} 2,447$ maka ada pengaruh antara variabel ROA terhadap PBV. Nilai signifikansi sebesar $0,009<0,05$ maka variabel ROA berpengaruh positif dan signifikan terhadap variabel PBV (Y). Penelitian ini sejalan dengan penelitian yang dilakukan oleh Amalia Nur Chasanah \& Daniel Kartika Adhi (2017), Rizka Annisa \& Mochammad Chabachib (2017), Medy Misran \& Mochamad Chabachib (2017), Ronny Catur Kushartono \& Nunung Nurhasanah (2017) bahwa perusahaan ini mampu secara maksimal mengelola dan mengembangkan ROA untuk meningkatkan PBV.

2. Variabel QR memperoleh nilai thitung sebesar $-3,201$, sedangkan $t_{\text {tabel }}$ adalah sebesar 2,447 . Lalu dibuatnya untuk memperbandingkan yakni $t_{\text {hitung }}-3,201>t_{\text {tabel }} 2,447$ maka ada pengaruh negatif antara variabel QR terhadap PBV. Nilai signifikan sebesar 0,019<0,05 maka variabel $Q R$ berpengaruh negatif dan signifikan terhadap variabel PBV (Y). Penelitian ini 
sesuai dengan penelitian yang dilakukan oleh Elisabeth Octavia Kamal \& Indra Widjaja (2019) bahwa perusahaan ini masih belum mampu mengelola dan mengembangkan QR untuk meningkatkan PBV.

\section{Uji Simultan (Uji F)}

Dipakai untuk membuktikan adanya pengaruh antara variabel independen yaitu ROA dan QR secara simultan terhadap variabel dependen PBV, dengan cara memperdibandingkan nilai $\mathrm{F}_{\text {hitung }}$ dengan $\mathrm{F}_{\text {tabel }}$ serta tingkat nilai signifikansi. Berpengaruh signifikan atau tidak, bisa dilihat dengan rumus $<0,05$ dan $F_{\text {hitung }}>F_{\text {tabel. }}$. Hasilnya bisa ditampilkan pada Tabel 11.:

\section{Tabel 11. Hasil Uji Simultan (Uji F) ANOVA $^{\mathrm{a}}$}

\begin{tabular}{lrrrrr}
\hline Model & $\begin{array}{c}\text { Sum of } \\
\text { Squares }\end{array}$ & df & $\begin{array}{c}\text { Mean } \\
\text { Square }\end{array}$ & F & Sig. \\
\hline Regression & 4,714 & 2 & 2,357 & 7,099 &, $026^{b}$ \\
1 Residual & 1,992 & 6 &, 332 & \\
Total & 6,706 & 8 & & & \\
\hline
\end{tabular}

a. Dependent Variable: Price to Book Value

b. Predictors: (Constant), Quick Ratio, Return On Assets

Sumber : Output SPSS Versi 20, Januari 2021

Titik Persentase Distribusi $F$ untuk Probabilita $=0,05$

\begin{tabular}{|c|c|c|c|c|c|c|c|c|c|c|c|c|c|c|c|}
\hline \multirow{2}{*}{$\begin{array}{l}\text { df untuk } \\
\text { penyebut } \\
\text { (N2) }\end{array}$} & \multicolumn{15}{|c|}{ df untuk pembilang (N1) } \\
\hline & 1 & 2 & 3 & 4 & 5 & 6 & 7 & 8 & 9 & 10 & 11 & 12 & 13 & 14 & 15 \\
\hline 1 & 161 & 199 & 216 & 225 & 230 & 234 & 237 & 239 & 241 & 242 & 243 & 244 & 245 & 245 & 246 \\
\hline 2 & 18.51 & 19.00 & 19.16 & 19.25 & 19.30 & 19.33 & 19.35 & 19.37 & 19.38 & 19.40 & 19.40 & 19.41 & 19.42 & 19.42 & 19.43 \\
\hline 3 & 10.13 & 9.55 & 9.28 & 9.12 & 9.01 & 8.94 & 8.89 & 8.85 & 8.81 & 8.79 & 8.76 & 8.74 & 8.73 & 8.71 & 8.70 \\
\hline 4 & 7.71 & 6.94 & 6.59 & 6.39 & 6.26 & 6.16 & 6.09 & 6.04 & 6.00 & 5.96 & 5.94 & 5.91 & 5.89 & 5.87 & 5.86 \\
\hline 5 & 6.61 & 5.79 & 5.41 & 5.19 & 5.05 & 4.95 & 4.88 & 4.82 & 4.77 & 4.74 & 4.70 & 4.68 & 4.66 & 4.64 & 4.62 \\
\hline 6 & 5.99 & 5.14 & 4.76 & 4.53 & 4.39 & 4.28 & 4.21 & 4.15 & 4.10 & 4.06 & 4.03 & 4.00 & 3.98 & 3.96 & 3.94 \\
\hline 7 & 5.59 & 4.74 & 4.35 & 4.12 & 3.97 & 3.87 & 3.79 & 3.73 & 3.68 & 3.64 & 3.60 & 3.57 & 3.55 & 3.53 & 3.51 \\
\hline 8 & 5.32 & 4.46 & 4.07 & 3.84 & 3.69 & 3.58 & 3.50 & 3.44 & 3.39 & 3.35 & 3.31 & 3.28 & 3.26 & 3.24 & 3.22 \\
\hline
\end{tabular}

Sumber : Distribusi $F_{\text {tabel }}$

Dari Tabel 11. menunjukan hasil nilai $F_{\text {hitung }}$ sebesar 7,099 nilai signifikannya yaitu $0,026^{b}$. Sedangkan $F_{\text {tabel }}=7$, hasil dari nilai $F_{\text {tabel }}=4,74$ sehingga $F_{\text {hitung }} 7,099>F_{\text {tabel }} 4,74$ Karena nilai signifikan $0,026^{\mathrm{b}}<0,05$. Dengan demikian bahwa variabel $\mathrm{ROA}$ dan $\mathrm{QR}$ secara simultan berpengaruh positif dan signifikan terhadap PBV.

\section{E. KESIMPULAN}

Dilakukannya penelitian ini agar bisa membuktikan ada atau tidaknya variable yang berpengaruh antara ROA dan QR terhadap PBV pada PT. Bukit Asam, Tbk, periode tahun 2011-2019. Dari hasil analisis data penelitian yang dilakukan maka dapat diberikan kesimpulannya seperti yang akan dijabarkan: 
1. Kinerja keuangan yang diproksikan oleh return on asset $(R O A)$ secara parsial berpengaruh positif dan signifikan terhadap nilai perusahaan yang diproksikan oleh price book value (PBV) pada PT. Bukit Asam, Tbk.

2. Kesehatan Keuangan yang diproksikan oleh quick ratio (QR) secara parsial berpengaruh negatif dan signifikan terhadap nilai perusahaan yang diproksikan oleh price book value (PBV) pada PT. Bukit Asam, Tbk

3. Kinerja keuangan yang diproksikan oleh return on asset (ROA) dan kesehatan keuangan yang diproksikan oleh quick ratio $(\mathrm{QR})$ secara simultan berpengaruh positif dan signifikan terhadap nilai perusahaan yang diproksikan oleh price book value (PBV) pada PT. Bukit Asam, Tbk

\section{DAFTAR PUSTAKA}

Annisa, R., \& Chabachib, M. (2017). Analisis Pengaruh Current Ratio (CR), Debt To Equity Ratio (DER), Return on Assets (ROA) Terhadap Price To Book Value (PBV), Dengan Dividend Payout Ratio Sebagai Variabel Intervening (Studi Kasus Pada Perusahaan Industri Manufaktur Yang Terdaftar di BEI Periode 2011-2014). Diponegoro Journal of Management, 6(1), 1-15.

Lutfi, A. M., \& Sunardi, N. (2019). Pengaruh Current Ratio (Cr), Return On Equity (Roe), Dan Sales Growth Terhadap Harga Saham Yang Berdampak Pada Kinerja Keuangan Perusahaan (Pada Perusahaan Manufaktur Sektor Makanan Dan Minuman Yang Terdaftar Di Bursa Efek Indonesia). Jurnal SEKURITAS (Saham, Ekonomi, Keuangan dan Investasi), 2(3), 83-100.

Chasanah, A. N., \& Adhi, D. K. (2017). Profitabilitas, Struktur Modal dan Likuiditas Pengaruhnya Terhadap Nilai Perusahaan Pada Perusahaan Real Estate yang Listed di BEI Tahun 20122015. Fokus Ekonomi, 12(2), 131-146.

Fahmi, I. (2014). Pengantar Manajemen Keuangan (Teori dan Soal Jawab). Bandung: Penerbit Alfabeta.

Husnan, S., \& Pudjiastuti, E. (2015). Dasar-Dasar Manajemen Keuangan, Edisi Ketujuh. Yogyakarta: UPP STIM YKPN.

Kasmir. (2010). Pengantar Manajemen Keuangan, Edisi Kedua, Cetakan Ke-7. Jakarta: Prenada Media Group.

Munawir. (2007). Analisa Laporan Keuangan, Edisi Keempat, Cetakan keempat belas. Yogyakarta: Liberty Yogyakarta.

Sugiyono. (2017). Metode Penelitian Kuantitatif, Kualitatif, dan R\&D. Bandung: Alfabeta cv.

Weston, J. F., \& Copeland, T. E. (2010). Manajemen Keuangan, Edisi Revisi Jilid 2. Jakarta: Binarupa Aksara Publisher

Kamal, E. O., \& Widjaja, I. (2019). Pengaruh Profitabilitas, Board Gender, dan Likuiditas Terhadap Nilai Perusahaan Dengan Kebijakan Dividen Sebagai Variable Moderasi (Studi Empiris Pada Perusahaan Manufaktur Yang Bergerak Dibidang Consumer Goods Yang Terdaftar di BEI Periode 2011-2016). Jurnal Manajemen Bisnis Dan Kewirausahaan, 3(3), 96-103.

Kushartono, R. C., \& Nurhasanah, N. (2017). Analisis Pengaruh Rasio Keuangan Terhadap 
Nilai Perusahaan Pada Perusahaan Yang Tergabung Dalam Indeks LQ45 Periode 2010 2016. Buana IImu, 2(1), 108-125.

Misran, M., \& Chabachib, M. (2017). Analisis Pengaruh DER, CR dan TATO Terhadap PBV Dengan ROA Sebagai Variabel Intervening (Studi pada Perusahaan Properti dan Real Estate yang Terdaftar pada BEI Tahun 2011 - 2014). Diponegoro Journal Of Management, $6(1), 1-13$.

Sunardi, N. (2019). Profitabilitas, Likuiditas, Dan Multiplier Equity Pengaruhnya Terhadap Harga Serta Return Saham Pada Industri Manufaktur Tahun 2012-2017. Inovasi, 6(1), 58-73.

Oktrima, B. (2017). Pengaruh Profitabilitas, Likuiditas, dan Struktur Modal Terhadap Nilai Perusahaan (Studi Empiris: PT. Mayora Indah, Tbk. Tahun 2011 - 2015). Jurnal Sekuritas Saham, Ekonomi, Keuangan Dan Investasi, 1(1), 98-107.

Priyanto, A. A. (2019). Faktor-Faktor yang Mempengaruhi Return On Assets (ROA). Jurnal IImu Manajemen, 9(1), 64-75.

Priyanto, A. A. (2021). Analisis Faktor-Faktor Yang Mempengaruhi Profitabilitas dan Implikasinya Pada Corporate Value. Jurnal KRISNA: Kumpulan Riset Akuntansi, 12(2), 190-204.

Yufita, A., \& Andayani. (2019). Pengaruh Kinerja Keuangan, Firm Size Terhadap Nilai Perusahaan: Dimoderasi Corporate Social Responsibility Tahun 2014-2017. Jurnal IImu Dan Riset Akuntansi, 8(3), 1-19. 